\title{
Small-mammal mycophagy in rangelands of central and southeastern Oregon
}

\author{
CHRIS MASER, ZANE MASER, AND RANDY MOLINA
}

\begin{abstract}
Most arid and semiarid rangeland plants form a mycorrhizal symbiosis with certain fungi through which the host plants absorb water and nutrients from the soil. Small mammals are known to disperse viable spores of hypogeous, mycorrhizal fungi in forests, but little is known about small mammals as vectors of fungal spores in rangelands. We therefore examined the stomach contents of 575 mammals (16 genera, 26 species) for fungal spores. Spores of hypogeous, mycorrhizal fungi, representing 15 genera, were identified from $21 \%$ of the mammals. Although wind and water are thought to be the main means of dispersal for fungal spores in rangelands, a variety of mammals may be locally important in dispersing spores of mycorrhizal fungi.
\end{abstract}

Key Words: mycorrhizal fungi, spore dispersal, plant succession, plant-animal mutualism

Most arid and semiarid rangeland plants form mycorrhizae. The importance of this symbiosis to the nutrition of most vascular plants and to the health of ecosystems has been demonstrated (Allen and Allen 1984, Trappe 1981). Mycorrhizal fungi absorb nutrients and water from soil and translocate them to a host plant; the host in turn provides sugars to the mycorrhizal fungi through photosynthesis. Fungal hyphae grow from the roots into soil and thereby serve as extensions of the root system. The hyphae are both physiologically and geometrically more effective for nutrient absorption than are the roots themselves (Maser et al. 1978, Trappe 1981). Both ectomycorrhizal and endomycorrhizal fungi provide similar benefits but are usually associated with different host plants.

Ectomycorrhizal fungi, mostly Ascomycetes and Basidiomycetes, predominate in coniferous forests in association with members of the Pinaceae; other dominant ectomycorrhizal host plants are confined to members of the Salicaceae, Betulaceae, and Fagaceae. Herbaceous plants and many woody plants on streambanks, in meadows and prairies, in early stages of forest succession, or in forest understories form vesicular-arbuscular (VA) mycorrhizae in association with fungi in the family Endogonaceae, Zygomycetes (Trappe 1981, Trappe and Maser 1977).

Knowledge of small-mammal mycophagy of mycorrhizal fungi has grown substantially during the last 30 years. Although the most extensive work has been on ectomycorrhizae of conifers in forest lands (Fogel and Trappe 1978, Maser et al. 1978), a few studies have shown in the importance of VA-mycorrhizal fungi of herbaceous plants in the diets of small mammals (Ponder 1980, Rothwell and Holt 1978, Whitaker 1962).

Mammals detect the belowground fruiting bodies of ectomycorrhizal fungi by the rather strong odors emitted by fruiting bodies as they mature (Maser et al. 1978, Trappe and Maser 1977). Some VA-mycorrhizal fungi form small fruiting bodies (Gerdemann and Trappe 1974) that can be detected by small mammals. A few small mammals, such as the deer mouse (Peromyscus maniculatus) and the Pacific jumping mouse (Zapus trinotatus), appear to specialize

\footnotetext{
Authors are research wildlife biologist, U.S. Department of the Interior Bureau of Land Management; research associate, Oregon State University Department of Forest Science; and research botanist, U.S. Department of Agriculture, Forest Service, Pacific Northwest Research Station-all are stationed at the Forestry Sciences Laboratory, $3200 \mathrm{SW}$ Jefferson Way, Corvallis, Oregon 97331.

We thank Edith Allen, Paul Doescher, Donald Grayson, and John Whitaker, Jr., for improving the manuscript.

Manuscript accepted 8 December 1987.
}

in feeding on the VA-mycorrhizal fungi (Gerdemann and Trappe 1974, Maser et al. 1978). VA-mycorrhizal spores have been found in stomachs of small mammals, and viable spores have also been recovered after passage through the intestinal tract (Ponder 1980, Rothwell and Holt 1978). Because little is known about smallmammal mycophagy on rangelands, we explored the dietary interactions of small mammals and mycorrhizal fungi with plants on the rangelands of central and southeastern Oregon.

\section{Methods and Materials}

Five hundred seventy-five mammals (16 genera and 26 species) were collected by snap-trapping or shooting from March through October from 1969 through 1978 in Jefferson, Klamath, Harney, and Malheur Counties within the High Lava Plains, Basin and Range, and Owyhee Upland physiographic provinces of Oregon. The major vegetational zones in the study area are: (1) steppe without big sagebrush (Artemisia tridentata wyomingensis); (2) shrub-steppe with big sagebrush; (3) desert shrub; and (4) western juniper (Juniperus occidentalis) (Dealy et al. 1981, Franklin and Dyrness 1973).

Voucher specimens of mammals were prepared using standard museum techniques (Hall 1981) and are housed in the Puget Sound Museum of Natural History, University of Puget Sound, Tacoma, Washington. Stomach contents were preserved separately in vials with $10 \%$ formalin, labeled, and stored for analysis.

Stomach contents were analyzed by shaking each vial to mix the material. Narrow, parallel-sided forceps were used to extract a sample extending from the bottom to the top of the vial. The material was placed on a microscope slide, a drop of Melzer's reagent (I, Kl, and chloral hydrate) was added, and a cover slip was put in place (Trappe et al., in press). Stomach contents were examined through a binocular microscope at 40 to 100 power magnification. Fungal taxa were recorded on one card per animal for each slide. Fungal taxa were identified with a spore key (Trappe et al., in press). The percent volume of fungal spores and sporocarps of each fungal taxon in each stomach was visually estimated to the nearest percent and recorded for each slide.

\section{Results and Discussion}

Results of our study showed that 21 of $\mathbf{2 6}$ species examined had eaten fungi in varying amounts. These are discussed by class.

Table 1. Percent (p) and range ( $r$ ) volume of stomach contents and percent frequency (f) of fungal taxa from 14 rabbits and hares (Leporidae).

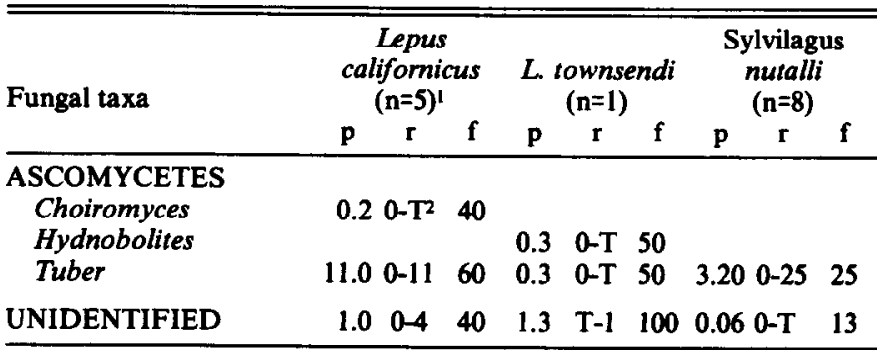

$I_{n}=$ number of animals sampled.

${ }^{2} \mathrm{~T}=$ trace. 
Table 2. Percent (p) and range (r) volume of stomach contents and percent frequency (f) of fungal taxa from 76 squirrels (Seiuridae).

\begin{tabular}{|c|c|c|c|c|c|c|c|c|c|c|c|c|c|c|c|c|c|c|}
\hline \multirow[t]{2}{*}{ Fungal taxa } & \multicolumn{3}{|c|}{$\begin{array}{c}\text { Ammospermophilus } \\
\text { leucurus } \\
(\mathrm{n}=9)^{1}\end{array}$} & \multicolumn{3}{|c|}{ E. minimus } & \multicolumn{3}{|c|}{$\begin{array}{c}\text { Spermophilus } \\
\text { beldingi } \\
(n=6)\end{array}$} & \multicolumn{3}{|c|}{$\begin{array}{l}\text { S. lateralis } \\
(n=15)\end{array}$} & \multicolumn{3}{|c|}{$\begin{array}{c}\text { S. townsendi } \\
(\mathrm{n}=22)\end{array}$} & \multicolumn{3}{|c|}{$\begin{array}{c}\text { S. washingtoni } \\
(n=5)\end{array}$} \\
\hline & $\mathbf{p}$ & $\mathbf{r}$ & f & $\mathbf{p}$ & $\mathbf{r}$ & $\mathrm{f}$ & $\mathbf{p}$ & $\mathbf{r}$ & $\mathbf{f}$ & $\mathbf{p}$ & $\mathbf{r}$ & $\mathrm{f}$ & $\mathbf{p}$ & $\mathbf{r}$ & f & $\mathbf{p}$ & $\mathrm{r}$ & f \\
\hline $\begin{array}{l}\text { ZYGOMYCETES } \\
\text { Glomus }\end{array}$ & 0.6 & $0-5$ & 11 & 1.1 & $0-20$ & 5 & & & & & & & & & & 0.1 & $0-10$ & 20 \\
\hline UNIDENTIFIED & 0.7 & $0-5$ & 33 & 30.0 & $0-30$ & 26 & 0.3 & $a-T^{2}$ & 50 & 0.7 & $0-10$ & 13 & 0.02 & $a-T$ & 5 & 6.8 & $T-10$ & 100 \\
\hline
\end{tabular}

in = number of animals sampled.

${ }_{2 \mathbf{T}}=\mathbf{T r a c e}$.

\section{The Fungus Consumers}

Lagomorpha: Leporidae (Rabbits and Hares)

Hares are normally thought of as vegetarians that feed only above ground; but Tuber formed 6 to $11 \%$ of the volume of stomach contents, and unidentified fungi ranged from 1 to $4 \%$ (Table 1). The mountain cottontail (Sylvilagus nuttalli) did not consume fungi as often as did the black-tailed jackrabbit (Lepus californicus) (Table 1), but Tuber ranged from a trace $(<1 \%)$ to $25 \%$ of the volume of stomach contents. Even the stomach of the one white-tailed jackrabbit (L. townsendi) (Table 1) had 1\% unidentified fungi.

\section{Rodentia: Sciuridae (Squirrels)}

The white-tailed antelope ground squirrel (Ammospermophilus leucurus) inhabits sparsely vegetated, volcanic ash soil types (edaphic habitats) in southeastern Oregon (Maser et al. 1979). These omnivorous squirrels eat a wide variety of foods from the seeds of Indian ricegrass (Oryzopsis hymenoides) to western whiptail lizards (Cnemidophorous tigris) (Bradley 1967, Howell 1937), but individual squirrels also ate fungi (Table 2).

Distribution of the yellow-pine chipmunk (Eutamias amoenus) is limited in Oregon rangelands to areas occupied by western juniper (Juniperus occidentalis), whereas the least chipmunk ( $E$. minimus) inhabits large, mature big sagebrush (Artemisia tridentata)(Bailey 1936, Maser et al. 1984). The yellow-pine chipmunk is an avid mycophagist in forested areas (Maser and Maser 1987, Tevis 1952), but we did not find fungi in the stomach contents of 5 individuals. In contrast, the least chipmunk has only been reported to eat fungi (Fogel and Trappe 1978), but in our sample the amount of fungi eaten by individual chipmunks was substantial (Table 2).

Of the 4 ground squirrels, the mantled ground squirrel (Spermophilus lateralis) is the only one that has long been known as a mycophagist, but only in forested areas (Tevis 1952, 1953). The Belding ground squirrel (S. beldingi) and the Townsend ground squirrel ( $S$. townsendi), which have broadly overlapping habitats, ate only trace amounts of unidentified fungi (Table 2). The Washington ground squirrel (S. washingtoni) ate up to $10 \%$ uni- dentified fungi by volume (Table 2). These 3 species of ground squirrels are generally thought of as meadow and rangeland animals. Mantled ground squirrels $S$. lateralis) are more often associated with forested areas, but populations occur in rangelands, primarily in talus (Bailey 1936, Maser et al. 1984) (Table 2).

\section{Geomytdae (Pocket Gophers)}

The large Townsend pocket gopher (Thomomys townsendi) normally inhabits geographically restricted deep valley soils; the small northern pocket gopher ( $T$. talpoides) is generally found on rangelands in relatively shallow, often stony soils above valley floors (Bailey 1936, Maser et al. 1984). Maser et al. (1978) reported epigeous fungi (mushrooms) in the diet of both gopher species. In this study, we could identify fungi from stomachs of pocket gophers only by class (Table 3). The Townsend pocket gopher ate less fungi (a trace to $2 \%$ ) than did the widely distributed northern pocket gopher (a trace to $10 \%$ ). One explanation may be that the Townsend pocket gopher is associated with agricultural crop lands, which have been artificially simplified compared with the rangelands where the northern pocket gopher lives, and may have lost their original species richness of hypogeous fungi.

\section{Heteromyidae (Heteromyid Rodents)}

We examined 4 species of heteromyid rodents: chisel-toothed kangaroo rat (Dipodomys microps), Ord kangaroo rat (D. ordi) (Table 3), dark kangaroo mouse (Microdipodops megacephalus), and Great Basin pocket mouse (Perognathus parvus). Although neither of the 2 dark kangaroo mice or the 38 Great Basin pocket mice had eaten fungi, Fogel and Trappe (1978) cite these heteromyid rodents as consumers of fungi.

\section{Cricetidae (New World Rats and Mice)}

Bushy-tailed woodrats (Neotoma cinereus) and desert woodrats (N. lepida) may or may not be sympatric, depending on the habitat. The bushy-tailed woodrat has a wide tolerance of habitats throughout Oregon, whereas the desert woodrat is found only in the very arid southeastern corner of the state (Bailey 1936, Maser et al. 1984). Bushy-tailed woodrats ate up to $20 \%$ unidentified fungi,

Table 3. Percent (p) and range ( $r$ ) volume of stomach contents and percent frequency (f) of fungal taxa from 55 pocket gophers (Geomyidae) and 39 heteromyid mice (Heteromyidae).

\begin{tabular}{|c|c|c|c|c|c|c|c|c|c|c|c|c|}
\hline \multirow[b]{2}{*}{ Fungal taxa } & \multicolumn{3}{|c|}{$\begin{array}{l}\text { Thomomys talpoides } \\
(\mathrm{n}=33)^{1}\end{array}$} & \multicolumn{3}{|c|}{$\begin{array}{c}T . \text { townsendi } \\
(\mathrm{n}=22)\end{array}$} & \multicolumn{3}{|c|}{$\begin{array}{c}\text { Dipodomys microps } \\
(\mathrm{n}=1)^{1}\end{array}$} & \multicolumn{3}{|c|}{$\begin{array}{l}\text { D. ordi } \\
(\mathrm{n}=38)\end{array}$} \\
\hline & $\mathbf{p}$ & r & f & $\mathbf{p}$ & $\mathbf{r}$ & f & $\mathbf{p}$ & $r$ & $\mathbf{f}$ & $\mathbf{p}$ & r & $\mathbf{f}$ \\
\hline ASCOMYCETES & 0.1 & $0-T^{2}$ & 18 & & & & & & & & & \\
\hline BASIDIOMYCETES & 0.2 & $0-T$ & 3 & & & & & & & & & \\
\hline $\begin{array}{l}\text { ZYGOMYCETES } \\
\text { Endogone } \\
\text { Glomus }\end{array}$ & & & & & & & & & & $\begin{array}{l}0.01 \\
0.01\end{array}$ & $\begin{array}{l}0-T \\
0-T\end{array}$ & $\begin{array}{l}1 \\
1\end{array}$ \\
\hline UNIDENTIFIED & 0.7 & $0-10$ & 15 & 0.3 & $0-2$ & 36 & 0.5 & $0-\mathrm{T}$ & 1 & 0.02 & $a-T$ & 5 \\
\hline
\end{tabular}

\footnotetext{
$i_{\mathbf{n}}=$ number of animals sampled.
}

2T $=$ Trace. 
Table 4. Percent (p) and range (r) volume of stomach contents and percent frequency ( $)$ of fungal taxa from 224 native rats and mice (Cricetidae).

\begin{tabular}{|c|c|c|c|c|c|c|c|c|c|c|c|c|c|c|c|}
\hline \multirow[b]{2}{*}{ Fungal taxa } & \multicolumn{3}{|c|}{$\begin{array}{l}\text { Neotoma cinerea } \\
\qquad(n=19)^{\prime}\end{array}$} & \multicolumn{3}{|c|}{$\begin{array}{c}\text { N. lepida } \\
(\mathrm{n}=\mathbf{8})\end{array}$} & \multicolumn{3}{|c|}{$\begin{array}{l}\text { Peromyscus crinitus } \\
\qquad(\mathrm{n}=44)\end{array}$} & \multicolumn{3}{|c|}{$\begin{array}{l}P . \\
(\mathrm{n}=146)\end{array}$} & \multicolumn{3}{|c|}{$\begin{array}{c}\text { Reithrodontomys } \\
\text { megalotis } \\
(\mathrm{n}=7)\end{array}$} \\
\hline & $\mathbf{p}$ & $\mathbf{r}$ & f & $\mathbf{p}$ & $\mathbf{r}$ & f & $\mathbf{p}$ & $\mathbf{r}$ & f & $\mathbf{p}$ & $\mathbf{r}$ & f & $\mathbf{p}$ & $r$ & f \\
\hline $\begin{array}{l}\text { ASCOMYCETES } \\
\text { Choiromyces } \\
\text { Hydnobolites }\end{array}$ & 0.02 & $0-T$ & 5 & 0.06 & $0-T^{2}$ & 13 & & . & & & & & & & \\
\hline $\begin{array}{l}\text { ZYGOMYCETES } \\
\text { Glomus }\end{array}$ & & & & & & & 0.01 & $0-T$ & 2 & 0.2 & $T-5$ & 10 & 0.07 & O-T & 14 \\
\hline UNIDENTIFIED & 1.1 & $0-20$ & 5 & & & & 0.02 & $0-T$ & 5 & 0.4 & T-51 & 12 & & & \\
\hline
\end{tabular}

$I_{\mathbf{n}}=$ number of animals sampled.
${ }^{2} \mathbf{T}=$ Trace.

but only a trace of fungi was found in any of the 8 stomachs from the desert woodrats (Table 4). The bushy-tailed woodrat eats both hypogeous and epigeous fungi in forest environments (34\% of stomach contents) (Maser et al. 1978).

Only 2 northern grasshopper mice (Onychomys leucogaster) were collected and neither had eaten fungi. Both the canyon mouse (Peromyscus crinitus) and the deer mouse ( $P$. maniculatus) had eaten fungi (Table 4). Peromyscus, particularly deer mice, have long been known to eat some fungi (Bakerspigel 1958, Hunt and Maser 1985, Williams and Finney 1964). That deer mice eat more fungi than canyon mice is not surprising because canyon mice live in areas (canyon walls) with few fungi. Deer mice, on the other hand, are ubiquitous. The western harvest mouse (Reithrodontomys megalotis), which inhabits moist areas with shrubs, ate no more than a trace of Glomus (Table 4).

\section{Arvicolidae (Voles)}

The sage vole (Lagurus curtatus) is locally abundant in central and southeastern Oregon where it inhabits sagebrush steppe up into the subalpine grasslands (Maser et al. 1974, Maser and Strickler 1978). Although sage voles eat spores of hypogeous fungi (Maser et al. 1978, Williams and Finney 1964), our study showed them to be potentially more important mycophagists than previously thought (Table 5).

Long-tailed voles (Microtus longicaudus) are local inhabitants of the sagebrush steppe (Bailey 1936, Maser et al. 1984). Glomus comprised up to $2 \%$ of the stomach contents; other fungi were eaten in trace amounts (Table 5). Montane voles ( $M$. montanus) are widely distributed, primarily in moist areas throughout central and eastern Oregon (Bailey 1936, Maser et al. 1984). Only trace amounts of fungi were found in their stomachs (Table 5).

Table 5. Percent (p) and range (r) volume of stomach contents and percent frequency (I) of fungal taxa from 120 voles (Arvicolidae).

\begin{tabular}{|c|c|c|c|c|c|c|c|c|c|}
\hline \multirow[t]{2}{*}{ Fungal taxa } & \multicolumn{3}{|c|}{$\begin{array}{l}\text { Lagurus } \\
\text { curtatus } \\
(\mathrm{n}=47)^{1}\end{array}$} & \multicolumn{3}{|c|}{$\begin{array}{c}\text { Microtus } \\
\text { longicaudus } \\
(\mathrm{n}=12)\end{array}$} & \multicolumn{3}{|c|}{$\begin{array}{c}\text { M. montanus } \\
(\mathrm{n}=48)\end{array}$} \\
\hline & $\mathbf{p}$ & $\mathbf{r}$ & $\mathbf{f}$ & $\mathbf{p}$ & $\mathbf{r}$ & f & $\mathbf{p}$ & $\mathbf{r}$ & $\mathrm{f}$ \\
\hline $\begin{array}{l}\text { ASCOMYCETES } \\
\text { Choiromyces } \\
\text { Hydnotyra }\end{array}$ & & & & 0.04 & $0-T^{2}$ & 8 & 0.01 & O-T & 4 \\
\hline $\begin{array}{l}\text { ZYGOMYCETES } \\
\text { Endogone } \\
\text { Glomus }\end{array}$ & $\begin{array}{l}0.01 \\
0.40\end{array}$ & $\begin{array}{l}0-5 \\
0-5\end{array}$ & $\begin{array}{c}2 \\
24\end{array}$ & 0.30 & $0-2$ & 17 & 0.01 & O-T & 4 \\
\hline $\begin{array}{l}\text { OTHER FUNGI } \\
\text { Coprinus } \\
\text { Unidentified }\end{array}$ & 0.20 & $0-21$ & 2 & $\begin{array}{l}0.10 \\
0.08\end{array}$ & $\begin{array}{l}0-T \\
0-T\end{array}$ & $\begin{array}{l}17 \\
17\end{array}$ & 0.02 & $0-T$ & 8 \\
\hline
\end{tabular}

$I_{n}=$ number of animals sampled

${ }^{2} \mathbf{T}=$ Trace.
Muskrats (Ondatra zibethicus) are locally restricted to marsh areas and to deep, slow water courses (Bailey 1936, Maser et al. 1984). Most of their food appears to be aquatic and semiaquatic vegetation (Maser et al. 1981), which may explain why none of the 13 muskrats had eaten fungi.

\section{Potential Interrelations}

Dispersal of mycorrhizal fungi is a many-faceted phenomenon. Wind and water may be more important than mammals as dispersal agents for fungal spores in open environments (Trappe 1981, Warner et al. 1985). MacMahon and Warner (1984) asserted that for physically rigorous environments, such as arid and semiarid lands, abiotic factors are more important for spore dispersal than are biotic factors. Dispersal of spores by abiotic means is broadbrush dispersal over vast areas and subject to the vagaries of terrain and weather.

Movement of infective mycelia is an alternative method of dispersing fungi (MacMahon and Warner 1984). Locally, mycelia can extend between plants, which requires only a suitable growing medium and the correct plant-to-plant distance. Either infected parts of plants or independent fragments of mycelia can be moved by animal vectors or abiotically. For example, a mammal or insect (Ponder 1980) may ingest infected parts of plants or fragments of mycelia in one place and excrete it as viable fungal inoculum elsewhere, thereby inducing local inoculation. Another possibility is that a small mammal can eat the fungal material and excrete it on the ground surface. Cattle (Bos taurus), can step on the feces and release the fungal inoculum for redistribution by wind or water. And simple soil disturbance by livestock might also allow wind or water to disperse fungal material. Burrowing animals, such as gophers and badgers, can move fungal material to the surface through digging; the spores are then redistributed as above.

Although fungal spores are dispersed over large areas by wind and water, spore dispersal by mammals probably affects only relatively small areas. If a small mammal, such as the least chipmunk (Table 2) or the sage vole (Table 5), is an avid mycophagist, then its contribution to moving mycorrhizal inoculum and to maintaining native vegetation could be substantial. If, on the other hand, small mammals, such as the Ord kangaroo rat (Table 3) or the deer mouse (Table 4), nip here and there on VA-mycorrhizal fungi in Endogonaceae and simultaneously use severely disturbed areas, then they will have a different function. They could, for example, play a role in plant succession by dispersing and concentrating viable spores of mycorrhizal fungi that help native vegetation to become established. This may be particularly important in severely disturbed areas inhabited primarily by a few introduced, nonmycorrhizal Old World species of plants (Allen and Knight 1984, Miller 1979, Seig et al. 1986).

In this study, animals ingesting enough spores of hypogeous, mycorrhizal fungi to deposit fecal pellets that could act as effective inoculum for native plants included black-tailed jackrabbit, mountain cottontail, white-tailed antelope ground squirrel, least chip- 
munk, deer mouse, sage vole, and long-tailed vole. Viable nitrogenfixing bacteria and yeast have also been found in the fecal pellets of the black-tailed jackrabbit and the sage vole ( $\mathrm{Li}$ et al. 1986).

\section{Conclusion}

Mycorrhizal fungi are obligatory symbionts of most arid and semiarid rangeland plants. Maintenance and dispersal of mycorrhizal populations is therefore critical to healthy rangelands. Although abiotic factors may predominate as dispersal mechanisms of fungal spores, some small mammals may play varying and possibly vital roles in the inoculation of specific, local rangeland plants with mycorrhizal fungi.

\section{Literature Cited}

Allen, E.B., and M.F. Allen. 1984. Competition between plants of different successional stages: mycorrhizae as regulators. Can. J. Bot. 62:2625-2629.

Allen, E.B., and D.H. Knight. 1984. The effects of introduced annuals on secondary succession in sagebrush-grassland, Wyoming. Southw. Nat. 29:407-421.

Bailey, V. 1936. The mammals and life zones of Oregon. N. Amer. Fauna. 55,416 pp.

Bakerspigel, A. 1958. The spores of Endogone and Melanogaster in the digestive tracts of rodents. Mycologia 50:440-442.

Bradley, W.G. 1967. Home range, activity patterns, and ecology of the antelope ground squirrel in southern Nevada. Southw. Nat. 12:231-252.

Dealy, E.F., D.A. Leckenby, and D.M. Concannon. 1981. Plant communities and their importance to wildlife. In: Wildlife habitats in managed rangelands-the Great Basin of southeastern Oregon. Gen. Tech. Rep. PNW-120, USDA Forest Serv. Pacific Northwest Forest and Range Exp. Sta., Portland, Ore.

Fogel, R., and J.M. Trappe. 1978. Fungus consumption (mycophagy) by small animals. Northw. Sci. 52;1-31.

Franklin, J.F., and C.T. Dyrness. 1973. Natural vegetation of Oregon and Washington. Gen. Tech. Rep. PNW-8, USDA Forest Serv. Pacific Northwest Forest and Range Exp. Sta., Portland, Ore.

Gerdemann, J.W., and J.M. Trappe. 1974. The endogonaceae in the Pacific Northwest. Mycologia Memoir No. 5:1-76.

Hall, E.R. 1981. The mammals of North America (Vol. II). John Wiley and Sons, New York. pp 1102-1132.

Howell, A.B. 1937. Food preferences of antelope ground squirrels. J. Mammal. 18:243-244.

Hunt, G., and Z. Maser. 1985. Consumption of hypogeous fungi by the deer mouse (Peromyscus maniculatus). p. 272. In: R. Molina (ed.) Proc. 6th North American Conf. on Mycorrhizae. Forest Res. Lab., Oregon State Univ., Corvallis.

Li, C.Y., C. Maser, and H. Fay. 1986. An initial survey of acetylene reduction and selected microorganisms in the feces of nineteen species of mammals. Great Basin Natur. 46:646-650.

MacMahon, J.A., and N. Warner. 1984. Dispersal of mycorrhizal fungi: processes and agents. p. 28-52. In: S.E. Williams and M.F. Allen (eds.) VA mycorrhizae and reclamation of arid and semi-arid lands. Sci. Rep. SA 1261. Wyoming Agr. Exp. Sta., Univ. Wyoming, Laramie.

Maser, C., J.M. Geist, D.M. Concannon, R. Anderson, and B. Lovell. 1979. Geomorphic and edaphic habitats. In: Wildlife habitats in managed rangelands the Great Basin of southeastern Oregon. Gen. Tech. Rep. PNW-99, USDA Forest Serv. Pacific Northwest Forest and Range Exp. Sta., Portland, Ore.
Maser, C., E.W. Hammer, C. Brown, R.E. Lewis, R.L. Rausch, and M.L. Johnson. 1974. The sage vole, Lagurus curtatus (Cope 1868), in the Crooked River National Grassland, Jefferson County, Oregon: a contribution to its life history and ecology. Saugertierk. Mitt. 22:193-222.

Maser, C., B.R. Mate, J.F. Franklin, and C.T. Dyrness. 1981. Natural history of Oregon coast mammals. Gen. Tech. Rep. PNW-133, USDA Forest Serv. Pacific Northwest Forest and Range Exp. Sta., Portland, Ore.

Maser, C., and G.S. Strickler. 1978. The sage vole, Lagurus curtatus, as an inhabitant of subalpine sheep fescue, Festuca ovina, communities on Steens Mountains -an observation and interpretation. Northw. Sci. 52:276-284.

Maser, C., J.W. Thomas, and R.G. Anderson. 1984. The relationship of terrestrial vertebrates to plant communities, part 2, appendices. In: Wildlife habitats on managed rangelands-the Great Basin of southeastern Oregon. Gen. Tech. Rep. PNW-172, USDA Forest Serv. Pacific Northwest Forest and Range Exp. Sta., Portland, Ore.

Maser, C., J.M. Trappe, and R.A. Nussbaum. 1978. Fungal-small mammal interrelationships with emphasis on Oregon coniferous forests. Ecology 59:799-809.

Maser, Z., and C. Maser. 1987. Notes on mycophagy of the yellow-pine chipmunk (Eutamias amoenus) in northeastern Oregon. Murrelet 68:24-27.

Miller, R.M. 1979. Some occurrences of vesicular-arbuscular mycorrhizal in natural and disturbed ecosystems of the Red Desert. Can. J. Bot. 57:619-623.

Ponder, F., Jr. 1980. Rabbits and grasshoppers: vectors of endomycorrhizal fungi on new coal mine spoil. Res. Note NC-250, USDA Forest Serv. North Central Exp. Sta., St. Paul, Minn.

Rothwell, F.M., and C. Holt. 1978. Vesicular-arbuscular mycorrhizae established with Glomus fasciculatus spores isolated from the feces of cricetine mice. Res. Note NE-259, USDA Forest Serv. Northeastern Forest Exp. Sta., Broomall, Penn.

Seig, C.H., D.W. Uresk, and R.M. Hansen. 1986. Seasonal diets of deer mice on bentonite mine spoils and sagebrush grasslands in southern Montana. Northw. Sci. 60:81-89.

Tevis, L., Jr. 1952. Autumn foods of chipmunks and golden-mantled ground squirrels in the northern Sierra Nevada. J. Mammal. 33:198-205.

Tevis, L., Jr. 1953. Stomach contents of chipmunks and mantled squirrels in northeastern California. J. Mammal. 34:316-324.

Trappe, J.M. 1981. Mycorrhizae and productivity of arid and semiarid rangelands. p. 581-599. In: Advances in food producing systems for arid and semi arid lands. Academic Press, N.Y.

Trappe, J.M., and C. Maser. 1977. Ectomycorrhizal fungi: interactions of mushrooms and truffles with beasts and trees. p. 163-179. In: Walters, Tony (ed.) Mushrooms and man, an interdisciplinary approach to mycology. Linn-Benton Comm. Coll., Albany, Ore.

Trappe, J.M., M.A. Castellano, Z. Maser, and C. Maser. Synoptic key to genera of hypogeous fungi of northern temperate forests with special reference to animal mycophagy. Mad River Press, Inc., Eureka, Calif. In Press.

Warner, N., J.A. MacMahon, and M.F. Allen. 1985. Dispersal of VAmycorrhizal fungi in a disturbed semi-arid ecosystem. pp. 292-293. In: R. Molina (ed.) Proc. 6th North American Conf. on Mycorrhizae. Forest Res. Lab., Oregon State Univ., Corvallis.

Whitaker, J.o., Jr. 1962. Endogone, Hymenogaster, and Melanogaster as small mammal foods. Amer. Midl. Natur. 67:152-156.

Williams, O., and B.A. Finney. 1964. Endogone-food for mice. J. Mammal. 45:265-271. 